\title{
THE HOUSE OF LORDS AND THE SHAPING OF THE SUPREME COURT
}

\author{
Mark Ryan, Senior Lecturer in Law, Coventry University.
}

\begin{abstract}
The Labour Government, since assuming power in 1997, has undertaken a significant legislative programme of reform which has reshaped the United Kingdom's uncodified constitutional arrangements. These changes have embraced, inter alia, freedom of information, devolution, human rights and the partial reform of the House of Lords. In relation to the latter, although the Government's protracted attempt at fully reforming the second chamber has faltered in recent times, it has however, been singularly more successful in reforming the judicial aspect of the House with the recent passage of the Constitutional Reform Act 2005. This legislation represents a watershed in terms of the judicial arm of the constitution, with the most significant element of it undoubtedly being the structural reform of the final court of appeal. In essence, the Act makes provision for the establishment of a Supreme Court of the United Kingdom together with the removal of the Law Lords from the House of Lords. As the dual constitutional position of the Law Lords (forming part of both the judiciary and legislature) has been one of the enduring and historic hallmarks of the constitution, this reforming measure did not pass through Parliament without considerable controversy and highly contentious debate. The constitutional significance of the Constitutional Reform Act 2005 should not be underplayed, and it is arguable that in terms of the judiciary, this is the most important legislation since the Act of Settlement was passed three hundred years earlier.
\end{abstract}

\section{Introduction}

The Constitutional Reform Bill ${ }^{1}$ was introduced in the House of Lords in February 2004 where it was comprehensively examined until December 2004. Thereafter, the Bill passed comparatively expeditiously through the House of Commons and secured the royal assent on the $24^{\text {th }}$ March 2005. The rationale behind this measure was to continue the process of modernising the United Kingdom's uncodified constitution and to realign it so that it further accorded with the doctrine of the separation of powers. The original main elements of the Bill, as introduced in February 2004, comprised the following: Part 1 (now Part 2 of the Act) proposed to abolish the constitutional office of the Lord Chancellor, a position which historically has infringed the separation of powers with the Lord Chancellor

1 HL Bill 30, 2003-04. 
simultaneously assuming legislative, executive and judicial ${ }^{2}$ roles. Part 2 (now Part 3) proposed the creation of a Supreme Court to replace the Appellate Committee of the House of Lords (hereafter the Appellate Committee). Part 3 (now Part 4) provided for the establishment of a statutory Judicial Appointments Commission to be responsible for recruiting and selecting judges in England and Wales, and which subsequently would then be subject to ministerial approval. The provisions of the Bill, were therefore, of seminal constitutional importance as they proposed to reform fundamentally, key and historic hallmarks of the United Kingdom's constitution. ${ }^{3}$ Although the measure as a whole has generated a vigorous and impassioned debate, the purpose of this article is to consider Part 3 of the Constitutional Reform Act 2005, which will establish a Supreme Court. In particular, in view of the scrutiny and amendment of the Bill's provisions in the second chamber, attention will focus largely on the passage of the legislation through the House of Lords. ${ }^{4}$

\section{The Chronology of Reform}

The antecedents of Part 3 of the Constitutional Reform Act 2005 (hereafter the Act) can be traced to the Government's announcement in June 2003 of its intention to consult on the creation of a Supreme Court for the United Kingdom..$^{5}$ It has, however, been suggested that it is difficult not to perceive these proposed reforms as "the product of policy making on the hoof." In fact, the policy behind the creation of a Supreme Court could hardly be characterised as a long term policy commitment given that, for example, on the $10^{\text {th }}$ June 2002 the previous Lord Chancellor, Lord Irvine of Lairg, made it clear in a written reply to Lord Lester of Herne Hill that the Government was not persuaded that a sufficient case for the abolition of the Law Lords,

2 It should be remembered that Lord Falconer of Thoroton, on assuming the office of Lord Chancellor in June 2003, indicated that he would not sit in a judicial capacity.

3 In fact, Andrew Le Sueur has stated that it "was difficult to overestimate the significance" of these changes: A. Le Sueur, "Judicial power in the changing constitution" in J. Jowell and D. Oliver (eds.), The Changing Constitution (5 $5^{\text {th }}$ ed., Oxford, 2004), p.344.

4 This article draws upon a number of points made in my written submission in April 2004 to the House of Lords Select Committee on the Constitutional Reform Bill which was subsequently published in July 2004 as part of its volume of evidence: Constitutional Reform Bill [HL] Volume 2: Evidence HL Paper 125 - II (2004), pp.401-402.

5 There is various literature on a Supreme Court and final courts of appeal which include the following: A. Le Sueur (ed), Building the UK's New Supreme Court: National and Comparative Perspectives (Oxford: 2004), A. Le Sueur and R. Cornes, The future of the United Kingdom's highest courts (London: The Constitution Unit, 2001), R. Cooke, "The Law Lords: An endangered heritage" (2003) 119 L.Q.R. 49, A. Le Sueur and R. Cornes, "What do the top courts do?" (2000) 53 C.L.P. 53, R. Cornes, Reforming the Lords: the Role of the Law Lords (London: The Constitution Unit, 1999) and a special issue of Legal Studies focusing on the creation of a Supreme Court: Constitutional innovation: the creation of a Supreme Court for the United Kingdom; domestic, comparative and international reflections (2004) 24 L.S.

6 A. Le Sueur, "The conception of the UK's New Supreme Court" in A. Le Sueur (ed.), Building the UK's New Supreme Court: National and Comparative Perspectives (Oxford, 2004), p.5. 
and their replacement with a Supreme Court, had been made out. ${ }^{7}$ More importantly from a constitutional perspective, Andrew Le Sueur has argued that in the context of the rather haphazard fashion of the announcement of the Government's reforms "the process of constitutional change - especially where the independence of the judiciary is at stake - is as important as the end result. It was not an encouraging start."' Nevertheless, in July 2003 the Department for Constitutional Affairs issued a consultation paper on the Government's proposals to replace the Law Lords with a Supreme Court. ${ }^{9}$ Although the paper invited responses to a series of questions concerning the Supreme Court (including an invitation for respondents to raise other points or make additional comments considered relevant), the consultation process itself was open to criticism on the basis that it was clearly premised on the assumption that the policy of a new Supreme Court had already been established and accepted. Consequently, the consultative process was somewhat circumscribed as it essentially focused on the mechanics of the responsibilities and form of the Supreme Court (for example, the number of judges and their appointment). Thereafter, on the $26^{\text {th }}$ November 2003 it was announced in the Queen's Speech ${ }^{10}$ that the Government intended to bring forward proposals to establish a Supreme Court together with provisions to abolish the office of the Lord Chancellor and to reform the system of judicial appointments (collectively, these elements were later to form the original draft of the Constitutional Reform Bill).

On the $26^{\text {th }}$ January 2004 Lord Falconer of Thoroton - the Secretary of State for Constitutional Affairs and Lord Chancellor - announced in Parliament details of a Concordat that had been reached with the Lord Chief Justice, Lord Woolf (acting on behalf of the judiciary), in respect of the Lord Chancellor's judiciary-related functions (on the basis of the office of the latter being abolished under the Bill). ${ }^{11}$ This Concordat is a constitutional watershed and has been described by Lord Woolf as "a remarkable document". ${ }^{12}$ Its aim was to clarify and specify in writing the partnership and constitutional framework between the executive and the judiciary and, in particular, to safeguard the latter's independence. ${ }^{13}$ The proposals contained within the Concordat included, inter alia, the handling of judicial complaints, discipline and training together with the clarification of the respective constitutional roles of the Secretary of State for Constitutional Affairs (the 'Minister') and Lord Chief Justice (the latter to assume the role of the Head of the Judiciary in England and Wales). Shortly afterwards, on the $9^{\text {th }}$ February 2004, Lord Falconer made a second Formal Statement to the House of Lords in which he set out a synopsis of the Government's proposals for the creation of a "new United Kingdom Supreme Court."14 These

7 HL Official Report vol.636 WA 310 June 2002.

8 Supra, n.6 at p.6.

9 Constitutional reform: a Supreme Court for the United Kingdom CP11/03 (2003).

10 Her Majesty's Most Gracious Speech to both Houses of Parliament (2003), p.2.

11 HL Official Report vol.657 cols.12-17 26 January 2004.

${ }^{12}$ H. Woolf, 'Shaping the Future' at <http://www.dca.gov.uk/judicial/speeches/Icj 141004.htm> (Last visited 3 January 2005).

13 The details of the Concordat were set out in Appendix 6 of the House of Lords Select Committee on the Constitutional Reform Bill: Constitutional Reform Bill [HL]: Volume 1: Report HL Paper 125-I, (2004), pp.202-224.

14 HL Official Report vol. 657 col. 9269 February 2004. 
provisions were subsequently to be published as Part 2 of the Constitutional Reform Bill (now Part 3 of the Act). The next day, the House of Commons Constitutional Affairs Committee (hereafter the Constitutional Affairs Committee) rather propitiously published the report ${ }^{15}$ of its inquiry into the Government's proposed reforms. It is pertinent to note in its conclusion that in view of the complexity of the issues raised by these reforms it recommended "that the Government proceed with the Constitutional Reform Bill on the basis of its being draft legislation - in particular in respect of the proposals for a new court of final appeal."16 (sic).

On the $24^{\text {th }}$ February 2004, the Constitutional Reform Bill $2004^{17}$ (hereafter the Bill) received its First Reading in the House of Lords. In fact, it is of interest to point out that the Bill, as originally drafted, comprised 104 clauses together with 15 schedules which were detailed in 212 pages, thereby indicating the extent, scale and complexity of these proposed constitutional changes. Shortly before the Second Reading of the Bill (which itself took place on the $8^{\text {th }}$ March) Lord Woolf delivered the Squire Centenary Lecture at Cambridge University in which he expressed reservations about the proposal to create a Supreme Court. In particular, he drew attention to the question of how the new court would be resourced and to Scottish concerns in relation to the court handling devolution issues. In addition, he put forward the possibility that a new Supreme Court "could act as a catalyst causing the new court to be more proactive than its predecessor. This could lead to tensions."18 Lord Woolf personally argued in favour of deferring a decision in respect of the Supreme Court until both of the following had been identified: viz., the accommodation to be occupied by the new court and the method to be used in determining the remainder of the non-judicial members of the House of Lords in the context of a fully reformed second chamber. Finally, he concluded by positing that to proceed with these reforms in the face of the reservations about them would run counter to the desirability of achieving consensual constitutional reform. ${ }^{19}$ Indeed, in view of the considerable reservations about the Bill as a whole, in the House of Lords on the $8^{\text {th }}$ March, Lord Lloyd of Berwick tabled a somewhat controversial amendment which would have the effect of committing the Bill to a Select Committee for further consideration (rather than committing the Bill to a Committee of the Whole House which is the normal parliamentary procedure). The House voted on this amendment and agreed to it by the significant margin of 216 votes to $183 .^{20}$ As a result, on the $22^{\text {nd }}$ March 2004 the 16 members of the House of Lords Select Committee on the

15 Judicial appointments and a Supreme Court (court of final appeal), First Report of Session 2003-04 Volume I: Report HC 48-I (2004).

16 ibid., at para.193.

17 HL Bill 30, 2003-04.

18 H. Woolf, 'The Rule of Law and a Change in the Constitution' (Squire Centenary Lecture) at <http://www.dca.gov.uk/judicial/speeches/Icj030304.htm> (Last visited 3 January 2005).

19 ibid. It should be noted that Lord Woolf indicated later his support for a Supreme Court in December 2004: HL Official Report vol.667 col.1556 20 Dec 2004.

20 HL Official Report vol.658 cols 1108-1110 8 March 2004. 
Constitutional Reform Bill (hereafter the Select Committee) were named, with Lord Richard as Chairman. ${ }^{21}$

The Select Committee was required to report to the House of Lords by the $24^{\text {th }}$ June 2004, and in due course it received voluminous and wide-ranging written and oral evidence relating to various aspects of the Bill. ${ }^{22}$ In fact, the Select Committee's second volume embodying this evidence has undoubtedly proved to be a valuable body of evidence on the issues raised by a Supreme Court and the abolition of the office of the Lord Chancellor. In April 2004, during the course of the Select Committee's deliberations, the Government published its response ${ }^{23}$ to the Constitutional Affairs Committee's report issued two months earlier. Finally, on the $2^{\text {nd }}$ July 2004 the report of the Select Committee was published, ${ }^{24}$ which set out its recommendations and which detailed the considerable number of agreed amendments - over 400 - that it had made to the Bill. The report made it plain that these amendments had "been made by agreement and on the basis that they improve and clarify the bill while leaving the main structure of the bill in its present form". ${ }^{25}$ Accordingly, the Bill was reprinted on the $24^{\text {th }}$ June as amended by the Select Committee. ${ }^{26}$ Thereafter it was recommitted to a Committee of the Whole of the House of Lords, and on the $13^{\text {th }}$ July 2004 the Bill commenced its Committee stage. Shortly afterwards the House of Lords Select Committee on the Constitution - whose remit is to examine the constitutional implications of all Public Bills - published a short report in respect of the Bill and noted that in the light of the comprehensive analysis of the issues already undertaken by the Select Committee, it would be otiose simply to replicate this work. However, it resolved to monitor the progress of the Bill - which after all, is a Public Bill of considerable constitutional import - and if necessary, would issue a further report at a later date. ${ }^{27}$

After the 2004 summer recess, the House of Lords continued the Committee stage of the Bill and in the Queen's Speech of $23^{\text {rd }}$ November $2004^{28}$ the Bill was carried over to the 2004-05 parliamentary session so that it did not run out of time. Without doubt, the most controversial aspect of the Committee stage was in respect of Part 1 of the Bill (now Part 2 of the Act) when the House of Lords voted by the significant margin of 240 votes to 208 to retain the office of the Lord Chancellor. ${ }^{29}$ Nevertheless, Lord Falconer made it clear that this decision would not preclude the Government from seeking to reverse this and restore the position of the Secretary of State for Constitutional Affairs when the Bill subsequently proceeded to the House of

21 The composition sensibly included Lord Falconer under whose aegis the Bill was being piloted through the House of Lords.

${ }_{22}$ Constitutional Reform Bill [HL] Volume 2: Evidence HL Paper 125-II (2004).

23 Judicial Appointments and a Supreme Court (court of final appeal), The Government's response to the report of the Constitutional Affairs Committee $(\mathrm{Cm}$. 6150: April 2004).

24 Constitutional Reform Bill [HL]: Volume 1: Report HL Paper 125-I (2004).

25 ibid., at para.7.

26 HL Bill 91, 2003-04.

27 Constitutional Reform Bill Report, $11^{\text {th }}$ Report of Session 2003-04, HL Paper 142 (2004), paragraph 4.

28 Her Majesty's Most Gracious Speech to both Houses of Parliament (2004), p.3.

29 HL Official Report vol.663 cols.1191-1194 13 July 2004. 
Commons. ${ }^{30}$ At the end of November 2004, the Joint Committee on Human Rights (hereafter the Human Rights Committee) published its report on the human rights implications of the Bill in terms of whether its provisions were consistent with international human rights obligations. ${ }^{31}$

In December 2004, the House of Lords voted effectively to codify the constitutional conventions that the holder of the office of the (newly retained) Lord Chancellor should not only be a member of the upper house, ${ }^{32}$ but also be a senior lawyer. ${ }^{33}$ It is clearly questionable whether the holder of the office of Lord Chancellor should be restricted to being drawn from the second chamber and it is contended that, as a result of his not inconsiderable powers and functions under this legislation, he should be an MP and held directly accountable to both the elected chamber and the electorate. On the other hand, the decision of the House of Lords to stipulate that the Lord Chancellor should be legally qualified did appear eminently sensible. In short, his responsibilities would seem to presuppose the possession of legal qualifications and experience as his duties would embrace, inter alia, the following: ultimately selecting Justices of the Supreme Court, defending judicial independence (section 3 of the Act) and the rule of law (section 1), together with implementation of the Concordat. On the $20^{\text {th }}$ December 2004, the Bill passed its Third Reading and was duly sent to the House of Commons for consideration. ${ }^{34}$ During its tortuous passage through the House of Lords, the Bill as a whole, but particularly the proposed abolition of the office of the Lord Chancellor, had generated a vigorous and protracted debate. It is of interest to note that had the House rejected the Bill, one consequence of the Government introducing it in the second chamber would have been that the Parliament Acts of 1911 and 1949 would have been inapplicable. In these circumstances, one option open to the Government would have been to have commenced the process again by introducing a new Constitutional Reform Bill in the House of Commons.

On the 21st December 2004 the Bill was introduced in the House of Commons and its Second Reading followed a few weeks later on the $17^{\text {th }}$ January 2005. At this point the Parliamentary Under-Secretary of State for Constitutional Affairs, Christopher Leslie MP, indicated that the Government had accepted the House of Lords' decision to retain the office and title of the Lord Chancellor as "many attach a symbolic value to the title." 35 The Bill, accordingly would seek to modify and reform the office of the Lord Chancellor, rather than simply abolish it. As a result, later in the House of

30 HL Official Report vol.665 col.13 11 October 2004. Lord Falconer also noted that the House would nevertheless proceed on the basis that the office of Lord Chancellor would still be reformed on the basis that the office holder would not sit as a judge or as the Head of the Judiciary and would be regulated by the terms of the Concordat together with the arrangements for the Judicial Appointments Commission (col.20).

31 Scrutiny of Bills: Final Progress Report, Twenty-third Report of Session 2003-04. Report, together with formal minutes and appendices HL Paper 210 HC 1282 (2004), pp.5-24.

32 HL Official Report vol.667 cols.776-779 7 December 2004.

33 ibid., at cols.785-788.

34 HL Official Report vol.667 col.1625 20 December 2004.

35 HC Official Report vol.429 col.558 17 January 2005. 
Commons, the remaining references to the 'Minister' in Part 3 of the Bill were replaced with references to the newly retained Lord Chancellor. In contrast, Christopher Leslie made it clear that the Government would seek to reverse the House of Lords' amendments to the Bill that had stipulated that the Lord Chancellor be both a member of the second chamber and be legally qualified. ${ }^{36}$ It is also of interest to note that the Shadow Attorney General, Dominic Grieve MP, attempted (unsuccessfully) to move that the House of Commons should decline to give the Bill a Second Reading on the basis that, inter alia, the proposal to establish a Supreme Court was costly, unnecessary and based on the erroneous premise that the separation of powers required the removal of the Law Lords from the legislature. In essence, notwithstanding the benefits of a Judicial Appointments Commission, the Bill "offers no convincing justification for replacing a system that works well." 37 Shortly after the Second Reading of the Bill, the Constitutional Affairs Committee published an update to its first report which had been issued in February 2004, which took into account the debate on, and amendments to the Bill that had occurred since the publication of its previous report almost a year earlier. ${ }^{38}$

As a result of comments made during the Second Reading that, by convention, a Bill of such constitutional importance should be debated on the Floor of the chamber, on the $31^{\text {st }}$ January 2005 Christopher Leslie announced that the programme of the Bill had been changed to allow the entire Committee stage of the Bill (which began that day) to take place on the Floor of the House. ${ }^{39}$ During the Committee stage the House of Commons voted to disagree with the House of Lords amendments that had insisted that the Lord Chancellor be a member of the House of Lords and be legally qualified. ${ }^{40}$ On the $1^{\text {st }}$ March 2005 the Bill successfully completed its Committee stage in the House of Commons and this was followed on the same day by it decisively securing its Third Reading by 280 votes to $118 .{ }^{41}$ Thereafter on the $15^{\text {th }}$ March 2005 the House of Lords considered the House of Commons amendments, and voted narrowly to disagree with the lower chamber's amendments to leave out the statutory requirements that the Lord Chancellor be both a peer and a lawyer. The next day, in response to this 'message' brought from the House of Lords, and in an attempt to break this "impasse" Christopher Leslie successfully moved in the House of Commons an amendment in lieu, to the effect that the Lord Chancellor should be qualified by experience ${ }^{42}$ (now section 2 of the Act). In short, 'A person may not be recommended for appointment as Lord Chancellor unless he appears to the Prime Minister to be qualified by experience' and that the latter may take

36 ibid., at col.559.

37 ibid., at col.573.

38 Constitutional Reform Bill [Lords]: the Government's proposals, Third Report of Session 2004-05 Volume I: Report, together with formal minutes HC 275-I (2005). A second volume detailed its written and oral evidence: Constitutional Reform Bill [Lords]: the Government's proposals, Third Report of Session 2004-05 Volume II: Oral and written evidence HC 275-II (2005).

39 HC Official Report vol.430 col.589 31 January 2005.

40 ibid., at cols.663-666 (clause 2 - membership of the House of Lords) and 681-4 (clause 3 - be legally qualified).

41 HC Official Report vol.431 cols.924-927 1 March 2005.

42 HC Official Report vol.432 cols.371-374 16 March 2005. 
into account experience, inter alia, as a Minister, as a member of either House of Parliament or as a qualifying practitioner. In short, although it would not be a statutory requirement for a future Lord Chancellor to sit in the second chamber, they would have to be qualified by appropriate experience. One week later the House of Lords voted to agree to these changes ${ }^{43}$ and three days later on the $24^{\text {th }}$ March 2005, the Bill obtained the royal assent. In essence, in many ways the debate on the Supreme Court in the House of Commons echoed the points which had earlier been made in the House of Lords, although the discussion in the lower chamber proved not to be as wide-ranging, detailed or as protracted. According to Martin Bowley QC, however, the passage of the Bill through the House of Commons had showed the chamber "at its worst" with a poor attendance in the chamber on the last day of the Committee stage. In addition, the day witnessed a significant number of clauses and amendments being approved which were not even debated. "It was a double disgrace." ${ }^{4}$

\section{The House of Lords Select Committee on the Constitutional Reform Bill}

The decision of the House of Lords in March 2004 to commit the Bill - a Government Public Bill - to a Select Committee was both politically controversial, and procedurally, a very unusual step to take. The consequence of this transfer meant that the Select Committee would be in a position to receive evidence relating to the Bill, determine if the Bill should proceed or not, and if it was decided that it should proceed, it could make amendments to it. During the debate in the House of Lords on this proposed committal a number of their Lordships spoke in favour of Lord Lloyd's amendment. For example, Viscount Bledisloe made it plain that he regarded the Bill as "thoroughly ill thought out", ${ }^{45}$ which, therefore, necessitated further scrutiny by a Select Committee. Lord Phillips of Sudbury argued that the Government's consultation in respect of the Bill had been very limited as they had simply "offered only two options; the status quo or what the Government had already decided". ${ }^{46}$ He added that committing the Bill to a Select Committee would be "in the best traditions of this House" 47 in the discharge of its parliamentary duty. Further, Lord McCluskey stated that although he welcomed Part 3 of the Bill (now Part 4 of the Act) which would establish a Judicial Appointments Commission, and in principle had no objection to the creation of a well thought out, established and resourced Supreme Court, he supported the amendment in the following terms: "I would hate to be accused of sinking a flagship, but I certainly would not mind if it were put into dry dock and had its bottom examined by a few experts - just to see whether it was seaworthy". ${ }^{48}$

Clearly the political controversy in respect of the committal of the Bill would have been obviated had the Government arranged full pre-legislative scrutiny

43 HL Official Report vol.671 cols.39-46 21 March 2005.

44 M. Bowley, "Playing truant?" (April 2005) Counsel p.14.

45 HL Official Report vol.658 col.1035, 8 March 2004.

46 ibid., at col.1086.

47 ibid., at col.1088.

48 ibid., at col.1032. 
of the Bill. It is argued that this should have been the appropriate course of action given the far-ranging constitutional changes envisaged by its provisions. This is particularly so in light of the somewhat inelegant manner in which these constitutional reforms had been announced in June 2003. As already noted, even before the First Reading of the Bill in the House of Lords, the Constitutional Affairs Committee had recommended that the measure was "a clear candidate for examination in draft", ${ }^{49}$ as it was concerned about the expeditious introduction of such fundamental reforms. Lord Crickhowell speaking in favour of the committal, conceded that even though a Select Committee would not "be as good as full pre-legislative scrutiny," 50 it would nevertheless provide the opportunity for evidence to be received in relation to the main issues raised by the Bill. An alternative to parliamentary pre-legislative scrutiny could have been for the Government to establish a Royal Commission to investigate comprehensively, and report on its proposed reforms. Indeed, in April 2003 the Joint Committee on House of Lords Reform in the context of the general reform of the second chamber, re-affirmed that there was a need for a full and public debate as to whether there should be a Supreme Court separate from Parliament. It formed the view that this was an issue which required "an inquiry of its own." 51 The Government's response to this specific point was to state that its July 2003 consultation paper, together with the resultant consultation exercise, would enable this public discussion to take place. ${ }^{52}$ As indicated earlier, it is a moot point as to whether this consultation process was satisfactory given its necessarily limited terms of reference. It is also of interest to remember that the Wakeham Royal Commission of 2000, although it considered the reform of the House of Lords in general, provisionally recommended that, subject to clarification of the constitutional conventions governing their role, the Law Lords "should continue to be ex officio members of the reformed second chamber and carry out its judicial functions." 53

Other Lordships strenuously opposed the transfer of the Bill to a Select Committee. Lord Carter, for example, stressed that the committal of a major Government Bill to a Select Committee was both unprecedented (the previous committal being in relation to the Hare Coursing Bill in the mid1970's, which in itself, had not been a major Government Bill) and inappropriate. ${ }^{54}$ In particular, he questioned whether a Select Committee comprising only 12 or 16 members should have the power to either recommend that a prominent constitutional Bill should not progress to its next stage, or alternatively, significantly amend it. ${ }^{55}$ Similarly, both Lord Falconer $^{56}$ and Lord Goodhart ${ }^{57}$ argued that the House collectively, rather than a small committee, should examine the Bill. In addition, Lord Carter

49 Supra, n.15 at p.56.

50 HL Official Report vol.658 col.1047, 8 March 2004.

51 House of Lords Reform: Second Report, HL Paper 97, HC 668 (2003), p.9.

52 House of Lords Reform: Government Reply to the Committee's Second Report, HL Paper 155, HC 1027, (2003), para.9.

53 A House for the Future, Cm. 4534 (2000), Recommendation 57.

${ }_{54}$ HL Official Report vol.658 col. 999, 8 March 2004.

55 ibid., at col.1001. In this context it is somewhat ironic that later, Lord Carter was to comprise one of the members of the Select Committee.

56 ibid., at col.1105.

57 ibid., at col.1100. 
also asserted that the committal "would be setting a very dangerous precedent" 58 as it would be clear that the consequence would be that the Bill would not be completed during the 2003-04 parliamentary session. It would therefore flout the constitutional convention that the Government was "entitled to get their business through without unreasonable delay." ${ }_{59}$ On this basis, it would have been possible, therefore, to argue that the committal could have been construed as unconstitutional. It is, however, pertinent to remember that the proposals contained in the Bill were not foreshadowed in either of the Labour Party manifestos of 1997 or 2001. In addition, Lord Goodhart regarded the amendment to commit the Bill to a Select Committee "as political mischief-making", ${ }^{60}$ whilst Lord Marsh bluntly stated that it amounted to "a blatant wrecking amendment". ${ }^{61}$ In contradiction of this, Lord Alexander of Weedon strenuously refuted such an argument and made it clear that his support for the committal was not based on "any view to killing this Bill", ${ }^{62}$ for, as he pointed out, the Select Committee could be given specific instructions to report within a stringent time-frame of three months. In the event, the Select Committee conducted its inquiry expeditiously as its instructions had indeed required it to report within three months. Finally, Lord Brennan was concerned that committing the Bill to a Select Committee could raise questions as to whether the House would be viewed as unnecessarily obstructive and whether confidence would remain in its capacity to process prominent legislative proposals. ${ }^{63}$

In view of the seemingly controversial and divisive nature of the Government's reforms, together with their fundamental constitutional ramifications, it does appear in hindsight to have been an appropriate decision - albeit a very unusual one - to commit the Bill to a Select Committee for further detailed investigation. This is particularly so in light of the absence of pre-legislative scrutiny of its provisions. In the event, in its report in January 2005, the Constitutional Affairs Committee commented that its first report together with the inquiry of the Select Committee and the Carry Over procedure, had in practical terms, given "the Bill the scrutiny that a draft Bill would expect to receive." 64 Indeed, from a constitutional perspective, reforms as far-reaching as these necessitate as much consideration, and consensus, as possible. Moreover, the decision to commit the Bill to a Select Committee for further scrutiny could hardly be characterised as undemocratic given that it was the Constitutional Affairs Committee in its first report that had recommended that the Bill be examined in draft. In this context, it is perhaps worth pointing out that during the Second Reading in the House of Lords it had been argued that Part 3 of the Bill (now Part 4 of the Act) establishing a Judicial Appointments Commission, which is comparatively uncontroversial, could be severed and

58 ibid., at col.1002.

59 ibid., at col.1002.

60 ibid., at col.1101.

61 ibid., at col.1044.

62 ibid., at col.1062.

63 ibid., at col.1027.

64 Constitutional Reform Bill [Lords]: the Government's proposals, Third Report of Session 2004-05 Volume I: Report, together with formal minutes HC 275-I (2005) para.13. 
legislated on separately. For example, Lord Donaldson of Lymington suggested that it was surely not beyond the ingenuity of the second chamber for "a number two Bill" to be introduced which would effectively embody this part of the Constitutional Reform Bill. ${ }^{65}$ It is, however, contended that the Bill comprised an intimately inter-connected and inter-dependent package of reforms that required enacting as a whole. In the event, during its passage through Parliament the Bill was considered as a composite measure.

It is interesting to note that during the Committee stage of the Bill in the House of Lords, Lord Falconer conceded that although he had initially opposed the committal of the Bill to a Select Committee, its deliberations had, however, proved to be beneficial. In particular, it had allowed proper consideration of the details and principles of the Bill and it had "made real progress in improving the Bill." 66 Later, he stated that the Select Committee had been essential in enabling evidence to be taken from the Senior Law Lord, Lord Bingham of Cornhill who, owing to constitutional principle, was not prepared to contribute to debates in the House of Lords. ${ }^{67}$ Any fears that the Select Committee would derail the Bill were dispelled at the outset of its report when it stated that the Committee had quickly taken the view that it would be inappropriate to prevent the Bill from continuing to its next stage. ${ }^{68}$ Instead, it focused on those aspects of the Bill that had raised issues warranting further consideration - these were detailed in its report - and where appropriate, the Select Committee had amended these clauses. Unsurprisingly, the Select Committee was divided over the underlying policy of whether or not there should be a Supreme Court (a self-evidently divisive issue). It did, nonetheless, serve a valuable constitutional purpose as it succeeded in agreeing a considerable number of the details of a Supreme Court. It therefore provided a useful and consensual blueprint.

\section{The Rationale Behind The Supreme Court}

Section 23 (Part 3) of the Act establishes a Supreme Court of the United Kingdom comprising 12 judges who, apart from the President and Deputy President, would be styled Justices of the Supreme Court. In tandem with this, section 137 (Part 6) of the Act effectively bars full time members of the Supreme Court from sitting and voting in the House of Lords while they hold that office. The constitutional arguments for a separate Supreme Court was set out by the Government in its July 2003 consultative paper and subsequently reaffirmed by Lord Falconer in Parliament and in his evidence to the Select Committee. In the consultation paper, the Government made it plain that the proposal to remove the Law Lords from the House of Lords, and reconstituting them elsewhere in a separate and free-standing Supreme Court, was part of its policy of modernising the United Kingdom constitution. ${ }^{69}$ In essence, the creation of a new Supreme Court would realign the separation of powers in the United Kingdom by legally separating the highest court and its judges from the legislature. In his memorandum to the Select Committee, Lord Falconer asserted that "The Law Lords are

65 HL Official Report vol.658 col.1052 8 March 2004.

66 HL Official Report vol.663 col.1183 13 July 2004.

67 HL Official Report vol.665 col.71 11 October 2004.

68 Supra, n.24 at para.7.

69 Supra, n.9 at para.1. 
judges and not legislators: the separation between those two roles should be made explicit. That principle of separation is already established in many other democracies." 70 In fact, it has been suggested that it is unusual for constitutional reform in the United Kingdom to be predicated on the basis of principle, as opposed to mere pragmatism. ${ }^{71}$ It is self-evident, therefore, that, at least in abstract and theoretical terms, a final court of appeal which forms part of the legislature clearly fails to adhere to the basic principles underpinning the doctrine of the separation of powers.

The Government in its consultation paper also argued that a new Supreme Court would redefine the constitutional relationship between the three arms of the constitution and place it "on a modern footing, which takes account of people's expectations about the independence and transparency of the judicial system." 72 Lord Falconer specifically commented that the present position of the Law Lords sitting in the legislature causes confusion. ${ }^{73}$ In addition, Lord Brennan questioned whether the public could possibly comprehend the subtle constitutional position of these judges forming part of Parliament as a distinct judicial committee, ${ }^{74}$ and Lord Goodhart described the combination of judicial and legislative functions as "a constitutional nonsense." 75 According to Christopher Leslie speaking in the House of Commons, the current status quo was problematic as "To anyone except a seasoned observer, it can appear that a legislative body is interpreting legislation." ${ }^{\prime}$ Furthermore, Lord Plant of Highfield asserted that if the Law Lords were to remain in the legislature they would continue to occupy a constitutionally privileged position, which amounted to "a form of double counting" which was in effect "procedurally unfair". ${ }^{77}$ In other words, their judgment would be counted twice, viz., once in the legislature (during the passage of legislation) and secondly in the courtroom (in the context of reviewing executive action). In light of the gradual constitutional expansion of the role of the judges via judicialisation, ${ }^{78}$ (through the process of judicial review and latterly under the aegis of the Human Rights Act 1998) it is contended that a more discernible constitutional division should be made between the three arms of government by way of the creation of a legally separate Supreme Court and, in the absence of its abolition, at the very least the reform of the office of the Lord Chancellor. According to Lord Steyn a new Supreme Court would serve as a public constitutional badge of judicial neutrality and independence. ${ }^{79}$ During the Committee Stage of the Bill in the House of Commons, Ross Cranston MP added that a separate Supreme Court

70 Supra, n.22 at p.9.

71 K. Malleson, "Modernising the constitution: completing the unfinished business" (2004) 24 L.S. 119.

72 Supra, n.9 at para.1.

73 HL Official Report vol.657 col.1217 12 February 2004.

74 ibid., at col.1303.

75 HL Official Report vol.665 col.66 11 October 2004.

76 HC Official Report vol.430 cols 735-736 1 February 2005.

77 HL Official Report vol.658 col.1076 8 March 2004

78 On the process of judicialisation see n.71, p.127.

79 J. Steyn, "The Case for a Supreme Court" (2002) 118 L.Q.R. 384. 
would illustrate "the fact that judges are functionally separate and that judges do judging." 80 (sic).

In practice, the dual constitutional role of the Law Lords has already resulted in the issuing (in June 2000) of a self-denying ordinance delivered by Lord Bingham as to the circumstances when it would be constitutionally inappropriate for them to participate in the proceedings of the second chamber. These would embrace matters which involve "a strong element of party political controversy" and where "they might render themselves ineligible to sit judicially if they were to express an opinion on a matter which might later be relevant to an appeal". ${ }^{81}$ Lord Falconer has made it clear that it was no longer desirable or sustainable to rely on this self-denying ordinance $^{82}$ and in this context it is interesting to note that attention has been drawn to the fact that the dividing line demarcating controversial issues under the ordinance is difficult to draw. ${ }^{83}$ Even the statement itself issued by Lord Bingham recognised that it was dealing with broad principles and that it was "impossible to frame rules which cover every eventuality". ${ }^{84}$ It is clearly the case that the notion of party political controversy is a necessarily nebulous and subjective term, which is incapable of precise definition. For example, is Part 4 of the Act relating to a Judicial Appointments Commission a matter of party political controversy? Although during its passage through the House of Lords it appeared to be a comparatively uncontested aspect of the Bill, it is nevertheless suggested that it is inextricably linked to the other main elements of the measure viz., reforming the office of Lord Chancellor and the creation of a Supreme Court, which are self-evidently highly politically controversial. For its part, the Human Rights Committee noted that notwithstanding the self-denying ordinance, "it is clear that there is still no sufficiently established constitutional convention separating the judicial branch from the legislative in politically controversial matters." ${ }_{55}$ In this context it is of interest to remember that two serving Law Lords - Lord Hoffmann and Lord Scott of Foscote - recently voted in 2004 during the passage of the highly contentious Hunting Bill. ${ }^{86}$ Although this clearly disqualifies them from sitting in a subsequent case involving this legislation, nevertheless it is suggested that it does serve to make further the case that an institutional separation should take place.

At the Second Reading of the Bill in the House of Lords, Lord Maclennan of Rogart commented that the removal of the Law Lords appeared sensible in practical terms "in that it avoids the embarrassment of judges having to rule themselves out of consideration of cases on matters that come up with which they may have had a legislative connection". ${ }^{87}$ In his oral evidence to the Constitutional Affairs Committee, Lord Bingham, an advocate of a Supreme

80 HC Official Report vol.430 col.727 1 February 2005.

81 HL Official Report vol.614 col.419 22 June 2000.

82 HL Official Report vol.665 col.73 11 October 2004.

83 Supra, n.71 at p.128.

84 HL Official Report vol.614 col.419 22 June 2000.

85 Supra, n.31 at p.21.

86 HL Official Report vol.665 cols 1214-1215 26 October 2004.

87 HL Official Report vol.658 col.1057 8 March 2004. 
Court, ${ }^{88}$ noted that the reason that there had been little difficulty with the Law Lords being part of the legislature was precisely because in recent years they had largely abstained from the business of the House. ${ }^{89}$ Furthermore, two years earlier in a lecture to the Constitution Unit he had asserted that as judges, the Law Lords "do not belong in a House to whose business they can make no more than a slight contribution." 90 At this point it is instructive to point out that the Select Committee in the appendix of its report usefully supplied a table ${ }^{91}$ which revealed that, up to the time of this report, of the twelve serving Law Lords, eight had made no interventions in debates in the second chamber. This is clearly a significant figure notwithstanding the fact that a number of these Law Lords are relatively recent appointments. Paradoxically, in the table the only interventions of Lord Nicholls of Birkenhead and Lord Hoffmann were in a debate on the Government's proposals for a Supreme Court (as already noted, Lord Hoffmann also voted on the Hunting Bill later in the year). It is clear that these statistics further support the case for a separate Supreme Court on the basis that the Law Lords, through constitutional self-restraint, already have a necessarily limited impact on the second chamber as evidenced by their infrequent interventions. Consequently, their departure would cause minimum disruption to the business of the House. In any event, in the House of Commons Simon Hughes MP usefully made the point that the Law Lords only become part of the legislature (and therefore become involved in its business) incidentally, as they are specifically and primarily appointed to the House to act as senior judges. ${ }^{92}$

Lord Falconer, in his memorandum to the Select Committee further supported the case for a separately constituted Supreme Court in terms of international law by reference to Article 6(1) of the European Convention on Human Rights. This Article is central to the independence of the judiciary and the rule of law. It requires that everyone is entitled to a fair and public hearing administered by an independent and impartial court/tribunal in terms of both perception and reality. To comply with the requirements of independence, the court must be independent of the parties, the executive and the legislature, ${ }^{93}$ and to comply with the principle of impartiality there should be "protection against actual and presumed bias". ${ }^{94}$ As in relation to domestic law, under the European Convention, appearances and perceptions are significant (viz., involving an objective test of impartiality). ${ }^{95}$ In his memorandum, Lord Falconer argued that the principle of judicial independence embodied within Article 6 needed "to be buttressed by appropriate and effective constitutional guarantees" and that these guarantees would be provided by the creation of a free-standing Supreme Court. ${ }^{96}$

88 T. Bingham, A New Supreme Court for the United Kingdom (London: The Constitution Unit, 2002).

89 Judicial appointments and a Supreme Court (court of final appeal), First Report of Session 2003-04 Volume II: Oral and written evidence HC 48-II (2004), Q446.

90 Supra, n.88 at p.6.

91 Supra, n.24 at pp.234-235.

92 HC Official Report vol.430 col.729 1 February 2005.

93 J. Simor (ed), Human Rights Practice (Sweet and Maxwell: 2002), 6.119.

94 ibid., at 6.123.

95 Piersack v Belgium (1982) 5 E.H.R.R. 169, para.30.

96 Supra, n.22 at p.10. 
Further, Andrew Le Sueur has suggested that part of the pressure exerted on the Government to establish a new Supreme Court may have been driven by a critical report concerning the dual constitutional position of the Law Lords by the Legal Affairs and Human Rights Committee of the Parliamentary Assembly of the Council of Europe. ${ }^{97}$

Moreover, it is without doubt that in the era of the Human Rights Act which gives further effect in domestic law to the Convention Articles - our existing constitutional arrangements will inevitably have to be viewed afresh in the light these principles which now have an immediacy about them. The question, however, as to whether in practice the Law Lords, by virtue of sitting within the legislature, contravenes Article 6 is arguably a moot point (notwithstanding the Pabla Ky case to be considered later). Andrew Le Sueur and Richard Cornes writing in May 2001, commented that although there had not as yet at that point been a legal challenge to the Law Lords under the European Convention, nevertheless "the footsteps of Article 6(1) are getting ever closer"98 as evidenced by Procola v Luxembourg ${ }^{99}$ and McGonnell $\mathrm{v} U K .{ }^{100}$ In this context it is pertinent to note that in November 2004, although the Human Rights Committee concluded that Article 6 did not per se require the removal of the Law Lords, it nevertheless argued that a free-standing Supreme Court "would make it much less likely that violations of Article 6(1) will occur in practice". ${ }^{101}$ It is clear that it would undoubtedly be the case that a final court of appeal, which is constitutionally, physically and visibly separate from Parliament, would inject a greater degree of clarity (and constitutional transparency) into the institutional structure of the United Kingdom's constitution. In short, the creation of a separate Supreme Court would, in both domestic and international terms, demonstrate a public commitment to the basic precepts of constitutionalism, viz., the rule of law, separation of powers and judicial independence. Accordingly, it is contended that Lord Falconer was right to assert in his Formal Statement to Parliament on the Supreme Court that "The time has come for the United Kingdom's highest court to move out from under the shadow of the legislature." 102

At a more practical and basic level, the case for a new Supreme Court has also been advanced on the basis that the present arrangements in terms of supporting, resourcing and accommodating the Appellate Committee of the House of Lords are inadequate. For example, in his memorandum to the Select Committee, Lord Falconer has made it plain that the present offices of the Law Lords were "cramped and inconveniently located."103 Richard Gordon QC who has appeared before the Law Lords has also urged the use

97 Supra, n.3 at p.335.

98 A. Le Sueur and R. Cornes, The future of the United Kingdom's highest courts (London: The Constitution Unit, 2001), p.53.

99 (1995) 22 E.H.R.R. 193

100 (2000) 30 E.H.R.R. 289

101 Supra, n.31 at p.21.

102 HL Official Report vol.657 col.926 9 February 2004.

103 Supra, n.22 at p.10. 
of larger accommodation. ${ }^{104}$ A separately housed and appropriately resourced Supreme Court would help to resolve these difficulties. Indeed, it is important that in the pursuit of the legal maxim that justice should manifestly be seen to be done, the public have appropriate physical access to the final court of appeal. Accordingly, with the establishment of a new Supreme Court, the public would symbolically be directed to a detached and visibly separate court (thereby reaffirming the independence of the final court in physical terms) as opposed to the present position whereby the public locate the Law Lords in a committee room of Parliament. Finally, it is also perhaps worth pointing out that the case for reform has significant and widespread support and currently includes the Bar Council, JUSTICE, the Law Society, five serving Law Lords ${ }^{105}$ (including the Senior Law Lord), together with a number of academics. Furthermore, on the $19^{\text {th }}$ of January 2005 a Sewel motion was passed by the Scottish Parliament (albeit narrowly by 63 votes to 56) that endorsed "the principle of having a clear and transparent separation between the judiciary and the legislature" and therefore agreed that the United Kingdom Parliament should consider the provisions of the Bill establishing a Supreme Court. ${ }^{106}$ It is also not without significance that towards the end of the passage of the Bill through the House of Lords, Lord Woolf, as Chairman of the Judges' Council indicated that this body was in favour of a Supreme Court (subject to an appropriate sunrise clause). ${ }^{107}$ Further, he had personally changed his view from initially being "weakly against the idea of a Supreme Court", ${ }^{108}$ to being in support of it.

\section{The Criticism of The Supreme Court}

Those opposing reform have argued, inter alia, that the case for reform has simply not been made out. In particular, Lord Norton of Louth has claimed that there was "a persuasive case" 109 for retaining our current constitutional arrangements in respect of the Appellate Committee and asserted that the onus was on those advocating reform to demonstrate its necessity. In particular, he questioned how a separately constituted Supreme Court could enhance the independence of the judges as "no one is arguing that the highest court of appeal is not a body of integrity and independence, what is there that needs enhancing? Physical separation will not enhance the independence of the Law Lords in their judicial deliberations." 110 Lord Lloyd of Berwick has added that everybody accepted that the Law Lords are already "completely independent." 111 In fact, Lord Falconer has repeatedly and consistently made it plain that the Government's proposals for reform should in no way be seen to represent criticism of how the current Law Lords have performed their

104 R. Gordon, "The Relationship between the Bar and the House of Lords" in A. Le Sueur (ed), Building the UK's New Supreme Court: National and Comparative Perspectives (Oxford: 2004), p.326.

105 These are Lord Bingham of Cornhill, Lord Steyn, Lord Saville of Newdigate, Lord Walker of Gestingthorpe and Baroness Hale of Richmond.

106 Scottish Parliament, Official Report Session 2 col.13661 19 January 2005.

107 HL Official Report vol.667 col.759 7 December 2004.

108 HL Official Report vol.667 col.1556 20 December 2004.

109 Supra, n.89 at Ev 115.

110 HL Official Report vol.657 col.1269 12 February 2004.

111 HL Official Report vol.665 col.56 11 October 2004. 
constitutional functions, ${ }^{112}$ and the Select Committee indicated in its report that one area of broad agreement was the high reputation and probity of the Law Lords. ${ }^{113}$ Moreover, it has been commented that the debate in respect of the independence of the judiciary in this context "has been conducted, overwhelmingly, in the abstract. The problem is posed as one of potential conflict." 114 (sic)

Furthermore, Lord Norton strenuously argued that although part of the Government's justification for change was driven by public confusion in respect of the role of the Law Lords, no empirical data had actually been presented to support this assumed misconception. Instead, "we are offered the Government's perception of perception." 115 Consequently, the case for reform was not proven as it was based on unsubstantiated presumptions. For its part, the Select Committee came to the conclusion that to the extent that it could gauge the perception of the public on this matter, and in respect of the proposed reforms, "the most we can say is that opinion does not run high"116 and fittingly, it added that few members of the general public had actually responded to the online e-consultation exercise that it had commissioned. Similarly, the Constitutional Affairs Committee stated in its first report that there was common agreement that the current system for appeals works, and therefore the case for change concerned "principle and perception." 117 In its written reply to this specific point, the Government reaffirmed that its proposals were indeed firmly founded on principle, viz., the constitutional principle that the judicial and the legislative arms of the constitution should not be blurred. Accordingly, in the $21^{\text {st }}$ century, as a matter of constitutional principle and propriety, the highest court of appeal should be separate from the legislature. ${ }^{118}$ This is after all, a principle that is a basic precept of other modern democracies and fundamental to constitutionalism.

One obvious criticism of the creation of a new Supreme Court being based on an adherence to the separation of powers is, of course, that the United Kingdom constitution does not strictly follow the doctrine in a pure sense in any case. In fact, Lord Lloyd of Berwick has bluntly asserted "that the separation of powers is not part of our constitution." 119 In any event, it must be remembered that the establishment of a separate Supreme Court would still leave in place a parliamentary executive whereby the executive is drawn from - and invariably dominates - the legislature. It is arguable that a case could be put forward that the constitutional and political implications of this breach of the separation of powers, and specifically the problem associated with the 'elective dictatorship' ${ }^{120}$ of recent decades, is more significant than that of the Law Lords. Yet there is no party political proposal (either in the

112 HL Official Report vol.657 col.926 9 February 2004.

113 Supra, n.24 at para.130.

114 J. Webber, "Supreme Courts, independence and democratic agency" (2004) 24 L.S. 59.

115 HL Official Report vol.657 col.1269 12 February 2004.

116 Supra, n.24 at para.117.

117 Supra, n.15 at para.23.

118 Supra, n.23 at p.7.

119 HL Official Report vol.665 col.57 11 October 2004.

120 On the concept of the elective dictatorship see: Lord Hailsham, "Elective dictatorship", Listener, 21 October (1976) pp.496-500. 
short or long term) for the executive to be separated from, and be independent of, Parliament. In contrast, however, the point has to be made that the executive does not always control the legislature. More importantly, from a constitutional perspective it is imperative in terms of the separation of powers and the rule of law that the judicial arm of the constitution is independent of both the legislature and executive.

In terms of the separation of powers it is instructive to draw attention to the fact that although the Government in its written reply to the Constitutional Affairs Committee's first report reaffirmed that the case for reform was founded on the need for the final court of appeal to be separate from the legislature, it also agreed with the Committee's recommendation that upon retirement, all judges of the Supreme Court should, subsequently, be appointed to the second chamber. ${ }^{121}$ In this context, Diana Woodhouse wisely has identified the pressure that could be exerted on those judges nearing retirement in the event of only specific judges being selected for appointment. ${ }^{122}$ In any event, it is contended that in the interests of constitutional clarity, and in view of the underlying raison d'être of the reforms, no retired Supreme Court Justices should be appointed to sit in Parliament. In fact, the appointment of Justices would become impossible in the (albeit unlikely) event that a future fully reformed second chamber would be wholly elected. It is also significant to point out that, during the Third Reading in the House of Lords, Lord Falconer urged their Lordships to support the proposal for a Supreme Court on the basis that a final court of appeal separate from the legislature would be consistent with other modern democracies and "not because of any slavish adherence to the doctrine of the separation of powers". ${ }^{123}$

In respect of the European Convention of Human Rights, the Select Committee noted in its report that a number of witnesses refuted the case that a separate Supreme Court was necessary in order to comply with Article 6. In particular, Sir Robert Carnwath stated that the European Court of Human Rights in Strasbourg "does not insist on a rigid division of functions between the judges and the legislature. It is concerned with specific connections in individual cases. The Law Lords have responded by a self-imposed restriction on participation in parliamentary debates." 124 According to Jeremy Webber in a recent article, the Law Lords have already taken the necessary steps to reduce the possibility of the appearance of bias and that therefore (for the most part) their participation in the legislative process which is "not charged with partisan significance", created no more appearance of bias than, for example, a Law Lord's comments in a lecture. ${ }^{125}$ This in turn, however, raises the question of whether judges, in any event, should deliver such lectures. In addition, the Constitutional Affairs Committee indicated in its first report that it had received evidence from judges suggesting that a legal challenge to a ruling of the existing Appellate

121 Supra, n.23 at p.10.

122 D. Woodhouse, "The constitutional and political implications of a United Kingdom Supreme Court" (2004) 24 L.S. 137.

123 HL Official Report vol.667 col.1566 20 December 2004.

124 Supra, n.22 at p.331.

125 Supra, n.114 at p.63. 
Committee based upon Article 6 would be very unlikely to succeed. ${ }^{126}$ Moreover, it has been asserted that such a challenge could "hardly be advanced after any serious thought." 127 For its part, the Human Rights Committee has suggested that there was scope for misunderstanding as to the requirements of Article 6 in terms of the separation between the legislature and the judiciary and concluded that there was no per se requirement that the Law Lords should be removed from Parliament. ${ }^{128}$ Further, Dominic Grieve, speaking in the House of Commons, asserted that if a challenge to the Law Lords were to be made in the European Court of Human Rights, "the margin of appreciation allowed for a country's individual judicial system would enable our arrangements to stand the test without difficulty." 129 Similarly, in the House of Lords, Lord Lloyd of Berwick stressed that the proposition that the constitutional dual position of the Law Lords violates Article 6 "is just plain wrong" 130 and made reference to the 2004 Strasbourg decision of Pabla Ky v Finland. ${ }^{131}$

This case concerned an MP of the Finnish Parliament, who in 1997 acted as an expert member of a panel of five members of the Court of Appeal that rejected the applicant's appeal. The applicant contended a violation of Article 6 on the basis that, as one of its expert members was also an MP, the court could not therefore be considered independent and impartial. A Chamber of the European Court of Human Rights reaffirmed that in order to satisfy the requirements of independence, regard had to be had to, inter alia, the presence of safeguards against external pressures and whether an appearance of independence was presented. In relation to impartiality, it was made clear that the court must subjectively be free of personal bias or prejudice. It should also be objectively impartial and "must offer sufficient guarantees to exclude any legitimate doubt in this respect."132 The court indicated that although the principle of the separation of powers had assumed increasing importance in the European Court's jurisprudence, nevertheless, Article 6 did not require:

"States to comply with any theoretical constitutional concepts regarding the permissible limits of the powers' interaction. The question is always whether, in a given case, the requirements of the Convention are met." 133

The European Court added that there was no objection per se to expert lay members being involved in the decision making in a court, and in relation to the specific facts of the case before it, noted that the MP - as part of the legislature - had not previously participated in the legislation which was in issue before the court. The nature of this case, therefore, was in contrast to the earlier decisions of Procola and McGonnell. In short,

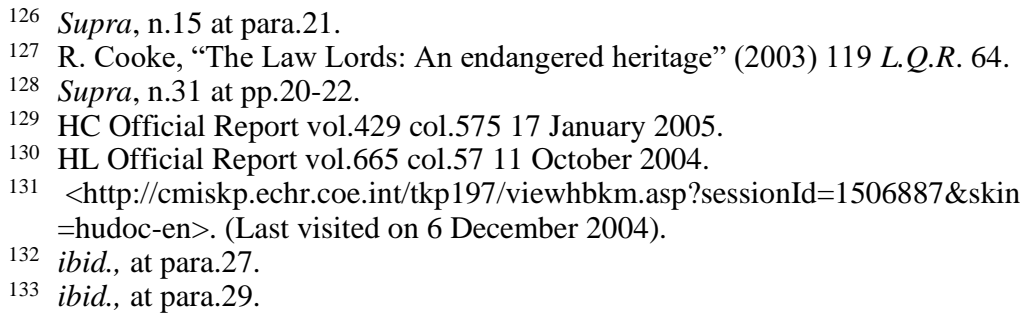


"The Court is not persuaded that the mere fact that M.P. was a member of the legislature at the time when he sat on the applicant's appeal is sufficient to raise doubts as to the independence and impartiality of the Court of Appeal. While the applicant relies on the theory of separation of powers, this principle is not decisive in the abstract." 134 (sic).

This would, accordingly, suggest that the current self-denying ordinance appears to satisfy the requirements of Article 6. One judge, Judge Borrego Borrego, however, dissented from the judgment, ${ }^{135}$ and it is of interest to remember that in the case, the MP was in a minority on the court as three professional judges outnumbered the two expert witnesses. In contrast, the position in the United Kingdom is that the entire panel of Law Lords determining an appeal forms part of the legislature. It is also perhaps significant that according to the European Court's judgment, from January 2003 the domestic law of Finland had been changed and that expert members no longer participate in proceedings before the Court of Appeal. The fact remains that a legal challenge to the constitutional duality of the Law Lords under Article 6 has not yet been realised in either the domestic courts under the Human Rights Act or in the European Court of Human Rights. Perversely, the former situation would raise the legal spectre of the Law Lords themselves ruling on this matter as it would no doubt be the case that in exhausting the domestic remedy - the issue would have to be litigated up to the final court of appeal. In any event, for a definitive determination, the issue would ultimately have to be tested in Strasbourg. Nevertheless, even if the current position of the Appellate Committee appears to be consistent with the requirements of the Convention, as noted above, the Human Rights Committee clearly have a case that, in practice, a separately constituted Supreme Court would in any event make it much less likely that a breach of Article 6 would occur. ${ }^{136}$

Opponents of a Supreme Court such as Lord Jauncey of Tullichettle have also argued that such a reform would provide no real practical benefit and was unnecessary. ${ }^{137}$ In addition, the Shadow Minister for Home Affairs, Jonathan Djanogly MP speaking in the House of Commons stated that this reform was modernisation of the constitution for the sake of it and asserted that the Bill (notwithstanding the creation of a Judicial Appointments Commission which was generally supported) represented "constitutional vandalism". ${ }^{138}$ In fact, it has been proposed that a Supreme Court could actually be harmful in two ways: Firstly to Parliament and secondly to the Law Lords themselves. With regard to the former, it has been suggested that the expulsion of the judges would mean that the second chamber (as part of the legislature) would lose the benefit of the Law Lords' judicial wisdom, ${ }^{139}$ together with their valued participation in the committee system. The removal of the Law Lords, however, would clearly not leave the House of Lords lacking in legal knowledge as other members of the chamber have

134 ibid., at para. 34

135 ibid., at pp.7-8.

136 Supra, n.31 at p.21.

137 Supra, n.22 at p.364.

138 HC Official Report vol.431 cols 917-918 1 March 2005.

139 As noted by Lord Borrie: HL Official Report vol.657 col.936 9 February 2004. 
valuable expertise in the law. Moreover, as already noted, the appendix supplied by the Select Committee listing the interventions of the serving Law Lords, illustrates the somewhat limited value they have currently in respect of the business of the House in any case. Indeed, in this context Lord Hope of Craighead commented in his oral evidence to the Constitutional Affairs Committee that, in practice, there was already almost a complete separation of the judiciary from the legislature ("if that is important") owing to the selfimposed absence of most of the Law Lords from the second chamber. ${ }^{140}$ It is plain, however, that these absences merely serve to indicate the necessarily limited role the Law Lords play in the non-judicial business of the House. Further, Lord Richard has pointed out that the contribution made by the Law Lords in the House was in essence made by those Law Lords who had retired. ${ }^{141}$

Secondly, it has been argued that a new Supreme Court could prove detrimental to the Law Lords themselves. Lord Craig of Radley has suggested that the level of constitutional protection that the Law Lords currently receive under the aegis of Parliament would be greater than that which might be enjoyed by judges in a constitutionally separate Supreme Court. ${ }^{142}$ Lord Norton has added that he feared that the establishment of a free-standing court could merely serve to constitutionally isolate the judiciary and leave them liable to criticism when they made controversial or unpopular decisions. ${ }^{143}$ It is clearly the case that in the contentious jurisdiction of judicial review the tension between the judicial and executive arms of the constitution has become more marked in the past two decades. ${ }^{144}$ This has undoubtedly been exacerbated with the enactment of the Human Rights Act 1998 and Kate Malleson has rightly commented that as a consequence of this Act, together with the advent of devolution, "politically and morally sensitive questions are more frequently coming before the courts." 145 The recent highly contentious case involving the indefinite detention without charge or trial of non-nationals suspected of international terrorist activity ${ }^{146}$ serves to underscore this point. In light of the above, it is contended that this further makes the case for a constitutionally separate Supreme Court which is visibly independent from the other arms of the constitution. Moreover, it is highly pertinent at this point to draw attention to the fact that the Act imposes a statutory requirement on the Lord Chancellor together with other Ministers, specifically to uphold the continued independence of the judiciary (section 3). The Human Rights Committee broadly welcomed this express statutory recognition of the principle of judicial independence which is typically enshrined in international

140 Supra, n.89 at Q281.

141 HL Official Report vol.667 col.1562 20 December 2004.

142 HL Official Report vol.657 col.1254 12 February 2004.

143 ibid., at col.1268.

144 On the constitutional tension between the judiciary and the executive in the context of judicial review, see H. Woolf, "Judicial review - The tensions between the executive and the judiciary" (1998) 114 L.Q.R. 579.

145 K. Malleson, "Selecting Judges in the Era of Devolution and Human Rights" in A. Le Sueur (ed), Building the UK's New Supreme Court: National and Comparative Perspectives (Oxford, 2004), p.295.

146 A and Others v Secretary of State for the Home Department, The Times 17 December 2004, p.78. 
instruments. ${ }^{147}$ Andrew Le Sueur, however, in commenting on the original draft of the Bill, pointed out the inherent difficulties with this attempt at codifying such complex conventions. ${ }^{148}$ In addition, he observed that the Bill failed "to locate, delimit, and entrench judicial power", ${ }^{149}$ which is part of the ideal of the "institutional autonomy" of a final court of appeal. ${ }^{150}$

Lord Nicholls of Birkenhead made a further argument against reform by suggesting that the separation of the final court of appeal from Parliament would result in the Law Lords losing out on the wider perspective provided by the second chamber of Parliament which, of course, "is not judge centred". ${ }^{151}$ In fact, Jeremy Webber has noted that there is a respectable argument that involvement in, and appreciation of, the law making process, enhances the judicial function "helping judges to avoid the simplistic caricatures of the legislative process". ${ }^{152}$ This implies, however, that those lower ranked judges not in Parliament are necessarily at a constitutional disadvantage, together with those judges in other Supreme Courts that are separated from their respective legislature. In any case, the mechanics, flavour and process of legislative debates are readily available through Hansard. Lord Nicholls also contended that as a new court, the Supreme Court would not enjoy the international reputation currently enjoyed by the Appellate Committee. ${ }^{153}$ Instead, the newly constituted court would be required to establish its reputation over time rather than inheriting that of its predecessor. It is suggested, however, that as section 24 of the Act would ensure that the first members of the newly created Supreme Court would be those judges acting as Law Lords immediately prior to the commencement of section 23 of the Act (the creation of the Supreme Court), it is equally arguable that the status and kudos associated with these Law Lords would be transferred to the nascent court.

Lord Hope of Craighead has drawn particular attention to the possible cost of a Supreme Court. He stressed that, in terms of efficiency and value for money, the present arrangements "cannot be bettered" 154 and Dominic Grieve speaking in the House of Commons added that in fact they are "astonishingly cheap". ${ }^{155}$ Indeed, one theme which ran throughout the debates as the Bill proceeded through the House of Lords, was the issue of cost (another being the question of accommodation). It is, of course, imperative that the proposals for the creation of a Supreme Court are "fully and accurately costed" 156 and the Government's case for reform was hardly assisted by the initial absence of specific and detailed figures as to all of the costs involved. In the event, in December 2004 Lord Falconer issued a written statement to Parliament specifying the running and capital costs of the new court. In short, the reforms would be approximately $£ 30$ million in capital terms

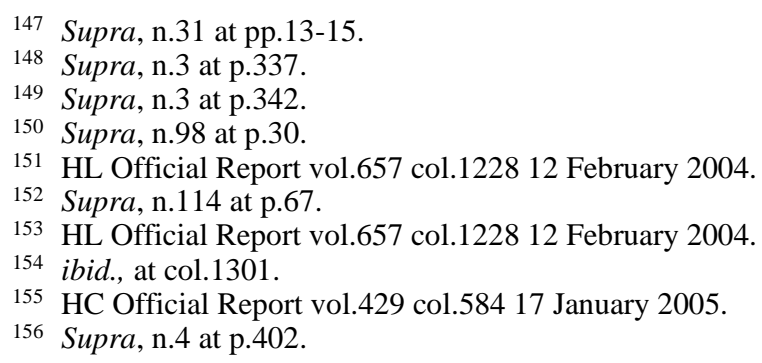


(renovating Middlesex Guildhall) together with $£ 15$ million for the relocation of other existing courts. ${ }^{157}$ The envisaged annual running costs for the new Supreme Court would be approximately $£ 8.4$ million (the current running costs of the Law Lords are approximately $£ 3.2$ million). As this represents an approximate annual increase of $£ 5.2$ million, this will necessarily ensure that, notwithstanding the passing of the Act, the cost/benefit analysis of the reform will continue to be keenly debated.

In view of the above range of arguments deployed in support of, and ranged against the policy of the establishment of a Supreme Court, it is not altogether surprising that the Select Committee was itself divided over the desirability of this reform proposal. ${ }^{158}$ Furthermore, it is also of interest to note that the persons who would be directly and intimately affected by the implementation of this measure, viz., the serving Law Lords, are themselves divided on the issue. For example, whereas the Senior Law Lord, Lord Bingham is in favour of a Supreme Court, ${ }^{159}$ the Second Senior Law Lord, Lord Nicholls of Birkenhead, is not. ${ }^{160}$ Notwithstanding the arguments levelled against the creation of a Supreme Court, it is strongly contended to be "a desirable and long overdue constitutional reform", ${ }^{161}$ as it will modernise the judicial arm of the constitution by finally, and visibly, severing the final court of appeal from Parliament. From a constitutional perspective a free-standing Supreme Court would necessarily realign our constitutional arrangements so that they would accord further with the principles underpinning the separation of powers. In international terms, it would represent a public declaration of constitutionalism and bring our constitution into line with other democracies where the judicial power is more clearly separated.

\section{The Nomenclature and Composition of The Supreme Court}

As part of its deliberations the Select Committee examined whether the terms Supreme Court and Justices of the Supreme Court were appropriate nomenclature. One difficulty is that the term Supreme Court, of course, already exists in England and Wales as an umbrella term for the courts of the High Court, Court of Appeal and the Crown Court. Similarly, the term is also in use in both Northern Ireland and Scotland. ${ }^{162}$ Accordingly, it is conceivable that the term Supreme Court could mislead. In this context the Select Committee also noted that "the bill does not create a new level of "United Kingdom" law separate from the laws of the three jurisdictions"163 (a point which Lord Falconer made clear earlier in Parliament as part of his Formal Statement to the House of Lords on the Supreme Court). ${ }^{164}$ Consequently, the new Supreme Court would not be a United Kingdom court processing United Kingdom appeals per se. Instead, it would operate as a

157 HL Official Report vol.667 WS 72-73 14 December 2004.

158 Supra, n.24 at para.132.

159 Supra, n.88.

160 HL Official Report vol.657 cols 1227-1229 12 February 2004.

161 Supra, n. 4 at p.401.

162 For example, in Scotland it collectively refers to the Court of Session and the High Court of Justiciary.

163 Supra, n.24 at para.147.

164 HL Official Report vol.657 col.927 9 February 2004. 
separate final court of appeal for each of the three distinct jurisdictions of England and Wales, Northern Ireland and Scotland (except in Scottish criminal appeals). ${ }^{165}$ In fact, apart from in relation to devolution matters, judicial decisions of the new Supreme Court in respect of an appeal from one jurisdiction would not be a binding judicial precedent in the others. This principle was given recognition in an amendment to the Bill (now section 41(2) of the Act). This section also usefully safeguards the different national identities of the jurisdictions of the United Kingdom by expressly protecting the distinction between them (section 41(1)). The Select Committee had earlier recommended that such an amendment to the Bill was desirable in order to safeguard these separate and distinct jurisdictions. ${ }^{166}$ Accordingly, section 41 should help prevent the new Supreme Court 'Anglicising' the other two legal systems in the United Kingdom.

A further reservation with the title of a Supreme Court was expressed by the Constitutional Affairs Committee which asserted that it "is not a happy choice" 167 as the term could mislead by intimating, erroneously, that the new Supreme Court would assume the constitutional power of the United States Supreme Court or any Supreme or Constitutional Court with the authority to invalidate primary legislation. Indeed, Lord Woolf initially cautioned in his Squire Centenary Lecture in March 2004 that although the new court would be called a Supreme Court, "Among the Supreme Courts of the world, our Supreme Court will, because of its more limited role, be a poor relation."168 In short, although the new court would process devolution issues, in essence it will simply assume the same constitutional position of that of the existing Appellate Committee. Notwithstanding the overriding constitutional force of European Community Law, ${ }^{169}$ the new Supreme Court would not threaten the fundamental precept of the United Kingdom constitution, viz., the legislative supremacy of Parliament. Nevertheless, it is contended that the nomenclature of the Supreme Court of the United Kingdom is appropriate. In fact, the current title of Appellate Committee of the House of Lords is apt to mislead the non-lawyer in any event. In support of the term Supreme Court, Lord Bingham in his oral evidence to the Select Committee was insistent that "it is the nearest we have got to the apex of the jurisdictional, rcurial pyramid in the jurisdictions of England, Wales, Scotland and Northern Ireland, and that is the proper name for it in my opinion." ${ }^{170}$ (sic). The Select Committee - with self-confessed different degrees of enthusiasm - agreed that both the titles of the Supreme Court and Justice of the Supreme Court were apposite, but that as a consequence of adopting them, the existing use of the term Supreme Court in other contexts should be altered. ${ }^{171}$ This appeared an eminently sensible conclusion and in the House of Commons the Bill was amended to the effect that the Supreme Court of England and Wales

165 In Scotland, under the new arrangements Scottish criminal appeals will continue to proceed to the High Court of Justiciary.

166 Supra, n.24 at para.283.

167 Supra, n.15 at para.101.

168 Supra, n.18.

$169 R$ v Secretary of State for Transport, ex parte Factortame Ltd (No. 2) [1991] 1 A.C. 603.

170 Supra, n.22 at Q434.

171 Supra, n.24 at para.153. 
was renamed the Senior Courts of England and Wales (section 59(1) of the Act). Similarly, the Supreme Court of Judicature of Northern Ireland was renamed the Court of Judicature of Northern Ireland (section 59(2)). It is further contended that the term Justice of the Supreme Court is appropriate and it is certainly preferable to the current term of Lord of Appeal in Ordinary, which no doubt confuses the non-lawyer.

As noted above, under the Act the Court would comprise 12 permanent judges, although section 38 makes provision enabling the court to have access, where necessary, to additional judges ('acting judges'), which would supplement the permanent membership of the court. As the newly constituted Supreme Court would process appeals from the three different jurisdictions of the United Kingdom, this will necessarily require that Justices, as is currently the case with the Law Lords, be recruited from each jurisdiction. The Act does not specify the number of judges to be recruited from each jurisdiction, which would appear to be a sensible approach as otherwise this would amount to a rigid quota system which plainly could cut across the requirement of merit. For its part, the Select Committee specifically recommended the continuation of the constitutional convention that at least two judges in the final court of appeal should be Scottish ${ }^{172}$ (the Constitutional Affairs Committee concurred with this in its report in January 2005). ${ }^{173}$ The Select Committee made no similar recommendation, however, in respect of Northern Ireland, although it is clearly the case that the practice of appointing one Law Lord from Northern Ireland is a less well established and settled constitutional convention. In any event, Brice Dickson has drawn attention to the constitutional anomaly of the Appellate Committee whereby the court had recently heard a number of appeals from Northern Ireland in which none of the presiding Law Lords had had personal experience of the Northern Irish legal system. ${ }^{174}$ In particular he made reference to Lord Hutton (who retired in 2004) who sat in only 6 out of 13 appeals from Northern Ireland since 1997. Furthermore, the position of Wales appears to have been completely overlooked. It has been highlighted that in view of the fact that Welsh devolved matters will be resolved by the Supreme Court as part of its jurisdiction, this raises the issue as to whether consideration should be given to one of the Justices being Welsh (or at least a judge with judicial experience in Wales). ${ }^{175}$

In terms of how the Supreme Court would sit, the Bill as originally drafted, required that in order to be duly constituted, the court must consist of an uneven number of judges, (with a minimum of three, to include at least one of whom would be a permanent judge). During the progress of the Bill in the House of Lords, concern was expressed that, as a consequence, the Supreme Court could, for example, theoretically consist of a panel of five judges, only one of whom, would be a permanent judge. ${ }^{176}$ In due course the Bill was later amended in the House of Lords to ensure that for a panel to be properly

172 Supra, n.24 at para.171.

173 Supra, n.64 at para.45.

174 B. Dickson, "A Constitutional Court for Northern Ireland?" in A. Le Sueur (ed.), Building the UK's New Supreme Court: National and Comparative Perspectives (Oxford, 2004), p.60.

175 Supra, n.122 at p.147.

176 Lord Goodhart, HL Official Report vol.665 col.105 11 October 2004. 
constituted, more than half of the judges have to be permanent (now section 42(1) of the Act). Following the practice of the Appellate Committee, the new Supreme Court would sit in uneven panels which would give it flexibility and allow the court to hear more cases than if it sat en banc, viz., with all Justices present. Although the Select Committee received evidence as to whether the new Supreme Court should sit en banc, as in the United States Supreme Court, it nevertheless agreed "that the Supreme Court should sit in panels, the size of which may be varied at the Court's discretion according to the importance of the case."177 In fact, Lord Bingham had earlier cautioned that if the final court of appeal were to sit en banc it would have the effect of resulting in "a savage reduction in the number of cases heard'. ${ }^{178}$

In any event, it is plain that it would be impossible for the final court to sit en banc if final court judges continued periodically, to be called upon to oversee inquiries. For example, Lord Saville of Newdigate has been involved in the Bloody Sunday inquiry since 1998. It is contended that in view of the importance of safeguarding judicial independence, the practice of using final court judges to chair inquiries - some of which are necessarily politically charged and controversial - should be discontinued. In addition, Diana Woodhouse has argued that in the interests of constitutional transparency, the way in which the final court undertakes its business in relation to the determination and selection of its panels, required reconsideration. ${ }^{179}$ Furthermore, Richard Gordon QC has rather interestingly suggested that, specifically in terms of important constitutional cases, the Law Lords should sit in a specialist panel. ${ }^{180}$ In terms of the delivery of its judgments, one innovation which could usefully be adopted by the new court, as noted by Diana Woodhouse above, would be for each judgment to be accompanied by a summary in plain English. This would undoubtedly make the final court more accessible to the public at large.

In respect of the qualifications required for appointments, in essence section 25 of the Act stipulates that these are the same as currently required for appointment to the existing Appellate Committee. ${ }^{181}$ On this point the Select Committee received written evidence from The Odysseus Trust which hoped that the criteria would be "sufficiently flexible" so as to embrace, for example, legal scholars. ${ }^{182}$ This would appear to be an interesting proposition given the nature of the role of the final court of appeal at the apex of the legal system, which is, in essence, to resolve very refined, sometimes esoteric, points of law. Indeed, other Supreme/Constitutional Courts include academics within their membership, as do the European Courts of Justice and of Human Rights. Moreover, the suggestion that the legal academic community should be included within the Supreme Court would undoubtedly widen its social diversity. In a recent article in 2003,

177 Supra, n.24 at para.171.

178 Supra, n.88 at p.10.

179 Supra, n.122 at pp.148-149.

180 Supra, n.104 at p.324.

181 Section 25 requires that a putative Justice should have either have held high judicial office for at least 2 years or have been a qualifying practioner for at least 15 years.

182 Supra, n.22 at p.382. 
however, Sir Sydney Kentridge cautioned that a Law Lord who lacked judicial experience or years in practice as a lawyer "would be at a considerable and possibly incurable disadvantage." 183 Nevertheless, recently, Baroness Hale of Richmond has been appointed to the Appellate Committee and she has both a judicial and academic background. It is also perhaps of interest to remember that the value of an academic perspective is expressly recognised in the Act. As already noted, the Prime Minister, in recommending a putative Lord Chancellor for appointment, may take into account, inter alia, 'experience as a teacher of law in a university' (section 2(2)(d) of the Act).

In terms of social composition, the lack of diversity in the judiciary generally is clearly a live issue as evidenced by the June 2003 Bar Council Working Party Report which made clear the desirability of greater diversity in the judiciary. ${ }^{184}$ In addition, in October 2004 the Department for Constitutional Affairs published a consultation paper into the lack of diversity in the judiciary as a whole. ${ }^{185}$ In relation to the final court of appeal, it is selfevident that this court is not fully representative of society (Baroness Hale, for example, is currently the only female member of the Appellate Committee). In fact, the lack of diversity in the court is thrown into sharp relief by cases such as $R \vee A^{186}$ where an all male panel of Law Lords determined the issue of the admission of evidence in a rape trial in the context of section 3 of the Human Rights Act. Notwithstanding this, it is contended that the introduction of a fixed quota system (for example, in terms of gender and ethnicity), to address this imbalance, would plainly cut across the principle of appointing Justices on the basis of merit, particularly as the pool of such applicants would necessarily be very restricted. Indeed, Sir Thomas Legg QC has sensibly advised that there was no room "for political correctness for its own sake" in the appointment of judges in general. ${ }^{187}$ It is pertinent to note that during its passage through the House of Commons, Part 4 of the Bill - concerning the Judicial Appointments Commission - was specifically amended to encourage diversity in the judiciary. As a result, section 64 of the Act requires the Commission, in exercising its functions under this Part of the Act, to 'have regard to the need to encourage diversity in the range of persons available for selection for appointments.' Significantly, this provision is made expressly subject to section 63 which, inter alia, stipulates that 'Selection must be solely on merit.'

\section{The Process of Appointment}

The process of appointing Justices to the Supreme Court is of considerable constitutional significance as it is paramount that this process, and consequently the Justices themselves, are perceived to be constitutionally

183 S. Kentridge, "The Highest Court: Selecting the Judges" (2003) 62 C.L.J. 62.

184 Bar Council Working Party on Judicial Appointments and Silk, The Bar Council (2003), pp.12-15.

185 Increasing Diversity in the Judiciary CP 25/04 (2004). In this context see A. Jack, "Number-crunching for diversity" (2004) vol.154 N.L.J. 1664.

186 [2001] 3 ALL ER 1.

187 T. Legg, "Brave New World - The new Supreme Court and judicial appointments" (2004) 24 L.S. 49. 
legitimate and acceptable. It is important to remember that, as noted above, although the original purpose of the Bill was to abolish the Lord Chancellor, as it was subsequently amended to retain this office, references to the 'Minister' in the earlier drafts of the Bill - and hence below - should now to be treated as a reference to the Lord Chancellor. In essence, the original draft of the Bill envisaged that in the event of a vacancy among the judges in the court, the Minister would have convened an ad hoc Supreme Court Selection Commission (hereafter the Selection Commission) which would have prepared for the Minister a list of two to five possible candidates. In preparing this list, the Selection Commission would have been required to consider the proscribed criteria laid down by the Minister and consult with senior judges. On receipt of this list, the Minister would also have been required to consult with the senior judges, which seemingly represented needless repetition of the consultation previously undertaken by the Selection Commission. In addition, the Minister would also have been required to consult with the First Minister in Scotland, the First and deputy First Ministers in Northern Ireland together with the National Assembly for Wales. It is arguable that this in itself is constitutionally inappropriate given that this consultation would take place between party politicians. In any case, the value of such comments proffered, certainly is open to question. Further, in relation to Wales, consultation would have been with a corporate body, as opposed to a specified individual office, and as such, as subsequently noted by the Select Committee, this necessarily raised issues of the maintenance of confidentiality in the consultation process. ${ }^{188}$ Finally, after deciding which candidate was most suitable for appointment, the Minister would then have notified the Prime Minister of the candidate, who in turn, would then have recommended that candidate to the Queen for appointment.

The process of appointing Justices to the Supreme Court, as originally proposed by the Bill, raised a number of issues: firstly, in relation to the role of the executive in the process and secondly, in respect of the discretion conferred. As far as the former is concerned, it is arguable from a constitutional perspective that the executive - in the form of the Minister should not be involved in the appointment of Justices of the Supreme Court given that, for example, these judges will inevitably be called upon to review the lawfulness of government action in judicial review proceedings (particularly under the aegis of the Human Rights Act 1998). It is suggested that a member of the cabinet vested with a wide and considerable discretion in the appointment of top level judges is inconsistent with the separation of powers. Nevertheless, there is widespread support for the principle that the executive be involved in the appointment of the judiciary. For example, Sir Thomas Legg QC in his oral evidence to the Constitutional Affairs Committee commented in relation to judicial appointments that "in my own view, the appointment of judges, and particularly of senior judges, is a political act in the broadest sense of the term" and therefore this power to appoint "should be primarily located in an accountable minister." 189 The role of the Minister, therefore, would represent accountability to Parliament for the appointments made. Similarly, Andrew Le Sueur and Richard Cornes

\footnotetext{
188 Supra, n.24 at p.52.
}

189 Supra, n.89 at Q251. 
have contended that it is clear that elected politicians should play some part in senior judicial appointments in view of "the political importance of the senior judges' roles". ${ }^{190}$ After all, the exercise of judicial power should not be excluded from the requirements of constitutional accountability. ${ }^{191}$ In addition, the Constitutional Affairs Committee in its first report argued that the appointments process to the Supreme Court must have "some level of democratic accountability". ${ }^{192}$

In essence, the argument in favour of directly involving the executive in the appointment process is to ensure that both the executive and Parliament (and indeed, the wider public) have confidence in the senior judiciary. Secondly, it would also avoid the constitutional spectre of a self-appointing judicial oligarchy. The question has to be asked, however, as to how accountable, in political reality, would the Minister actually be to Parliament for the appointments sanctioned. For example, Baroness Hale has already questioned the existing parliamentary arrangements in terms of securing accountability for appointments currently made. She has pointed out that, to her knowledge, neither the Lord Chancellor nor the Prime Minister is ever actually questioned in Parliament about individual judicial appointments that they had approved. ${ }^{193}$ It is plain, therefore, that if the executive is entrusted with the constitutional responsibility for ultimately making these senior appointments, there must be improved parliamentary scrutiny and examination of these highly significant decisions.

Although the Bill was premised on the basis of direct executive involvement in the appointment of Justices of the Supreme Court, there was nevertheless criticism of the breadth of the discretion conferred on the Minister under the Bill as originally drafted, namely, the selection of a candidate from a list of between two and five names submitted to him. Notwithstanding that the Minister, in theory, would be accountable to Parliament for the exercise of this power, it is plain that such a list of candidates would have conferred an "unacceptably wide" 194 measure of discretion on him. Arguably, it could leave room for political manipulation in the appointments to the highest court. In fact, it is pertinent to remember that the Government's consultation paper of July 2003 favoured, (in the context of the different possible models of a selection commission) in the light of "the likely limited field of candidates", ${ }^{195}$ a Selection Commission putting forward the names of one or two candidates only. Moreover, these names in any case would go to the Prime Minister. Further, even before the Bill was published, Lord Goodhart, though an advocate of a Supreme Court, described a list of five candidates as absurd. For example, he argued that even in the context of two names being submitted it would provide the executive with the opportunity to ignore the clearly outstanding candidate - but who happened to be unpopular with the Government at the time - and instead choose the less outstanding

190 Supra, n.98 at p.122.

191 A. Le Sueur, "Developing mechanisms for judicial accountability in the UK" (2004) 24 L.S. 74

192 Supra, n.15 at para.57.

193 B. Hale, “A Supreme Court for the United Kingdom?" (2004) 24 L.S. 42.

194 Supra, n.4 at p.401.

195 Supra, n.9 at para.41. 
candidate. ${ }^{196}$ For its part, the Select Committee stated that one name only should be submitted to the Minister and amended the Bill on this basis. ${ }^{197}$

In any event, it is debatable if (as the Act stipulates) a member of the executive is to be directly involved in the appointment process for putative Justices of the Supreme Court - a role, which is of paramount constitutional importance - it should be a figure with the constitutional gravitas of the Prime Minister. This is notwithstanding the fact that the office of the Lord Chancellor has now been retained under the Act and replaced references to the 'Minister'. Conversely, the role of the Prime Minister in the appointment process is essentially formalistic and mechanical as he simply recommends to the Queen the candidate that has been notified to him. ${ }^{198}$ Nonetheless, the Select Committee concluded (in relation to the original draft of the Bill) that within the context of appointing Justices to the Supreme Court, the respective roles of the Minister and Prime Minister were appropriate, with the latter simply acting as a conduit between the Queen and the Minister. It therefore recommended no change to the Bill. ${ }^{199}$ As indicated above, as the Bill progressed through the House of Lords, the Supreme Court appointment process originally detailed in its provisions was subject to a number of amendments. Thereafter, this amended appointment procedure was subsequently endorsed by the House of Commons (although references to the 'Minister' in the Bill were replaced with those of the newly retained office of the Lord Chancellor). A summary of the revised procedure (now sections 25 to 31 of the Act) is detailed below.

In the event of a vacancy, the Lord Chancellor would convene a Supreme Court Selection Commission ${ }^{200}$ which would select one candidate for recommendation. During the selection process, section 27 specifies that the Selection Commission would be required to consult with the senior judges, the Lord Chancellor, the First Minister in Scotland, the Secretary of State for Northern Ireland (pending the resumption of devolution) together with the Assembly First Secretary in Wales. Under section 27, in making a selection, the Selection Commission would be specifically required to ensure that selection was on merit and that, collectively, the Justices would 'have knowledge of, and experience of practice in, the law of each part of the United Kingdom' (section 27(8)). This latter provision thereby obviates the need for a statutory quota of a specified number of judges for each jurisdiction to be set out in the Act. In addition, regard would also have to be had to any guidance issued by the Lord Chancellor as to relevant matters to take into account in making a selection (section 27(9)). Thereafter, under

196 HL Official Report vol.657 cols 932-933 9 February 2004.

197 Supra, n.24 at para. 189.

198 Section 26(3)(b) of the Act expressly states that the Prime Minister may not recommend any other person other than the person that has been notified to him under section 29.

199 Supra, n.24 at para.200.

200 Under Schedule 8, Part 1, para.1 to the Act, the composition of the Selection Commission would comprise the President and Deputy President of the Supreme Court together with one member of each of the following: the Judicial Appointments Commission, the Judicial Appointments Board for Scotland and the Northern Ireland Judicial Appointments Commission (at least one of these members must not be non-legally qualified). 
section 28 the Selection Commission would submit a report to the Lord Chancellor in which it would state the candidate selected.

It is noteworthy to point out that although the Bill had been amended so that the Selection Commission would put forward one candidate only, nevertheless, the Constitutional Affairs Committee in its report in January 2005 recommended that an amendment be made so as to allow the Selection Commission the opportunity, when appropriate to do so, of the choice of supplying more than one name in the event of there being two or more equally appointable candidates. ${ }^{201}$ Notwithstanding this, under the revised procedure agreed under the Act, on receiving the report from the Selection Commission, the Lord Chancellor in turn would then consult the judges aforementioned, the First Minister in Scotland, the Secretary of State for Northern Ireland together with the Assembly First Secretary in Wales, thereby needlessly replicating the consultation already undertaken by the Selection Commission. In respect of Wales, the Bill as originally drafted, stipulated ministerial consultation with the National Assembly. As noted above, during the passage of the Bill concerns were expressed in relation to the issue of confidentiality in consulting with a corporate body. As a result, in the House of Lords an amendment was successfully moved which had the effect of substituting the National Assembly with the Assembly First Secretary instead. Following this consultation, under section 29, the Lord Chancellor had in effect three options as detailed below.

Firstly, the Lord Chancellor could accept the selection and notify the name to the Prime Minster who in turn would then recommend that person to the Queen for appointment. Secondly, the Lord Chancellor could reject the selection (in writing and with reasons section 30(3)), although the power to reject was only exercisable under section 30(1) on the basis that in the Lord Chancellor's opinion the proposed candidate was not suitable for office. Thirdly, the Lord Chancellor could require the Selection Commission to reconsider $^{202}$ its selected candidate (in writing and with reasons section 30(3)). If at Stage 1 the Lord Chancellor decided to reject the selection of the Selection Commission, at Stage 2 of the process, the Lord Chancellor must either accept and notify the Prime Minister of the selected candidate put forward at this stage or require the Selection Commission to reconsider its selection (for the latter, the conditions set out in section 30(2) and (3) would still apply). If the latter option is taken, at Stage 3 of the process, the Lord Chancellor, with one exception, ${ }^{203}$ would have to accept the Selection Commission's selection made at this stage and notify the Prime Minster of it. Alternatively, if at Stage 1 the Lord Chancellor required the Selection Commission to reconsider its selection, at Stage 2 of the process, the Lord

201 Supra, n.64 at pp.17-18.

202 This power is only exercisable under section 30(2) on the grounds that in the Lord Chancellor's opinion there was insufficient evidence that the person was suitable for office, there was evidence that in terms of merit the person was not the best candidate, or that there was insufficient evidence that this appointment would ensure that, collectively, the judges of the court would 'have knowledge of, and experience of practice in, the law of each part of the United Kingdom.'

203 Section 29(5). In essence, if a name which 'the Lord Chancellor required to be reconsidered at stage 1 or 2 was not selected again at the next stage, the Lord Chancellor' at stage 3 could then notify that name to the Prime Minister. 
Chancellor must either accept and notify the Prime Minister of the selected candidate made at this stage or reject the selection (for the latter, the conditions set out in section 30(1) and (3) would still apply). If the latter option is taken, at Stage 3 of the process, the Lord Chancellor, with one exception (as above in section 29(5)), would have to accept the Selection Commission's selection made at this stage and notify the Prime Minister of it. Although this revised appointments process clearly fetters the discretion of the Lord Chancellor, the unnecessarily convoluted nature of it will, however, do little to either aid public understanding of the process or to enhance the transparency of the appointments procedure.

\section{Jurisdiction}

In terms of its jurisdiction, section 40 of the Act - rather conservatively simply transfers the current legal jurisdiction of the Appellate Committee of the House of Lords in appellate matters to the newly created Supreme Court. In other words, the Supreme Court would function as the final court of appeal for each of the separate jurisdictions of England and Wales, Northern Ireland and Scotland (except for Scottish criminal appeals, which would continue to proceed to the High Court of Justiciary). In relation to Scotland, the Select Committee examined whether Scottish criminal appeals should proceed to the new Supreme Court, but saw no need to alter the Bill to allow the Supreme Court to have jurisdiction over these matters. ${ }^{204}$ On this issue, Andrew Le Sueur and Richard Cornes have observed that one consequence of Scottish criminal appeals being resolved within Scotland is that it necessarily denies Scottish criminal defendants access to the highest United Kingdom court of appeal. ${ }^{205}$ In fact, it is of course arguable that this current jurisdictional anomaly could, in effect, be characterised as a legal variant of the West Lothian question which has been transposed into the Act. In other words, in the new Supreme Court, whereas the Scottish Justices would be able to determine English and Welsh criminal appeals, the reverse would not apply. Consequently, the continuation of this anomaly requires clear and cogent justification. In any event, the case for a new Supreme Court assuming responsibility for Scottish criminal appeals is plainly strengthened by the fact that the new court will process Scottish devolution matters (as detailed below) which could themselves involve Scottish criminal law or procedure.

In relation to Scottish civil appeals, the Act adopts a continuation of the current practice whereby appellants in Scottish civil appeals - unlike appellants in the rest of the United Kingdom - would not be required to seek leave/permission in order to access the final court of appeal. The Select Committee declined to recommend a change in this respect. ${ }^{206}$ Accordingly, leave to appeal to the new Supreme Court will not be a universal requirement. This does appear to be a striking constitutional inconsistency and requires more justification than simply being an historic anomaly. It is pertinent to note that in the House of Commons Annabelle Ewing MP unsuccessfully moved an amendment which would have had the effect of

\footnotetext{
204 Supra, n.24 at para.226.

205 Supra, n.98 at p.69.

206 Supra, n.24 at para.244.
} 
repatriating Scottish civil appeals by preventing final appeals in civil cases proceeding to the new Supreme Court. It was defeated overwhelmingly by 411 votes to $4 .{ }^{207}$

In one respect the new Supreme Court would enjoy additional constitutional responsibility as section 40(4) Schedule 9(b) of the Act transfers devolution jurisdiction (for example, whether the Scottish Parliament had exceeded its legal powers) from the Judicial Committee of the Privy Council to the newly constituted Supreme Court. Under section 41(3)(b) decisions of the Supreme Court made in respect of a devolution matter will be 'binding in all legal proceedings' (in other words, in all three jurisdictions) and in this sense, therefore, the new court would represent a Supreme Court of the United Kingdom with a United Kingdom-wide jurisdiction. As Andrew Le Sueur has observed, the devolution legislation, together with the Human Rights Act, are already areas of law that could "meaningfully" be called UK Law.' ${ }^{208} \mathrm{He}$ also indicated that one expectation concerning the status of the top-level court of the United Kingdom is for it to operate as " a national institution of and for the whole UK" with unifying functions. ${ }^{209}$ Further, the Government argued in its consultation paper that a Supreme Court resolving devolution matters would avoid the current possibility of jursiprudential inconsistency in the Human Rights Act 1998 case law between the Judicial Committee of the Privy Council and the Appellate Committee. In other words, it would avoid a conflict in human rights jurisprudence, between on the one hand, the Appellate Committee processing ordinary appeal cases involving the Human Rights Act 1998 and, on the other, the Privy Council determining devolution issues with a human rights dimension. In short, a new Supreme Court would "restore a single apex to the UK's judicial system where all the constitutional issues can be considered." ${ }^{210}$ (sic). In fact, Aidan O'Neill QC in his memorandum to the Select Committee indicated that the current arrangements had already pointed "to certain tensions in the manner in which these two courts have been operating to date as courts for the whole of the United Kingdom." 211 It seems clear, therefore, that a Supreme Court assuming a devolution jurisdiction would help ensure that a consistent approach is taken in respect of the ever increasing and important jurisprudence generated by the Human Rights Act.

\section{Final Issues}

One matter on which the Act is silent is the issue of the establishment of a parliamentary committee (joint or otherwise) to act as a link between the judiciary and Parliament. Although under the Act the judges in the final court of appeal would be separated from the legislature, it is important that these Justices do not become isolated and operate in a constitutional vacuum. A parliamentary committee could be convened to facilitate communication and manage the constitutional relationship between these two arms of the constitution. It is also possible that the newly created ad hoc Supreme Court Selection Commission could report to this committee in respect of the

207 HC Official Report vol.430 cols 755-758 1 February 2005.

208 Supra, n.6 at p.10.

209 Supra, n.6 at p.9.

210 Supra, n.9 at para.20

211 Supra, n.22 at p.384. 
performance of its functions. In fact, it has been pointedly argued that although the Government issued its consultation paper on its proposals, the issue of the relationship between Parliament and the newly constituted court had been neglected in the context of the overall general debate on a Supreme Court. Yet this is a matter which should have necessarily formed part of any package of reform. ${ }^{212}$ In addition, it is arguable that in order to strengthen further this communication, putative Justices of the Supreme Court, immediately after the appointment process had been completed, could be introduced to Parliament. This could, for example, be usefully performed by a joint committee of both Houses of Parliament.

In respect of parliamentary confirmation hearings in general, Kate Malleson has commented that such examinations would provide some information on the ideological beliefs of final court judges, as it is arguable that such scrutiny "is precisely what is lacking in the present system." 213 It is clear that this process would inevitability increase public awareness of, and no doubt interest in, putative Justices of the Supreme Court. For its part, although the Select Committee concluded in principle, that although it would be desirable for a parliamentary committee to act as a bridge between the two arms of the constitution, nevertheless, it made it plain that "Such a committee should not seek to hold individual judges to account." 214 This view was subsequently endorsed by the Human Rights Committee. ${ }^{215}$ Although the issue of a parliamentary committee is now one for Parliament itself to decide in due course, in this context it is perhaps pertinent to draw attention to an amendment to the Bill (now section 5 of the Act) which was moved by Lord Woolf. ${ }^{216}$ This section sensibly facilitates dialogue between, on the one hand, Parliament and the other, the 'chief justice of any part of the United Kingdom' (section 5(1)). In essence, it enables these judges to lay written representations before Parliament in respect of important issues relating to the judiciary, or the administration of justice, in that part of the United Kingdom.

One final issue that was not addressed by the original draft of the Bill was the question of accommodation. At the time of the introduction of the Bill in February 2004, permanent premises (quite understandably) had not been acquired to house the proposed new Supreme Court. Consequently, during the passage of the Bill in the House of Lords, the issue was raised as to whether the operation of the part of the Bill relating to the Supreme Court, should be suspended pending appropriate accommodation being secured. The Select Committee was divided over the issue of whether this part of the measure should be delayed in these circumstances and therefore made no recommendation on this issue. ${ }^{217}$ Notwithstanding this, the insertion of a sunrise clause into the Bill appeared an eminently sensible option to take. ${ }^{218}$ Indeed, it would be self-evidently incongruous for the Supreme Court to come into operation with the newly created Justices sitting in Parliament

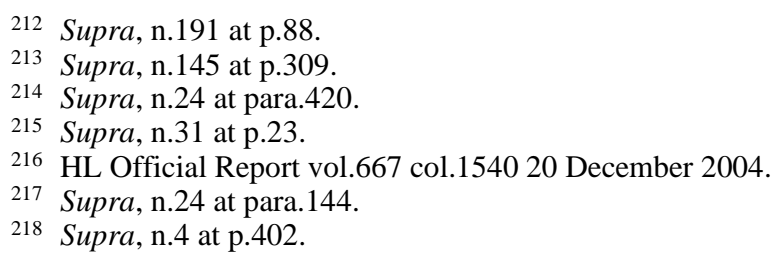


waiting for appropriate accommodation to be arranged. In April 2004 the Government stated that it was inevitable that it would take time to identify the best location for the new Supreme Court, but insisted that it was "for the Government to decide how best to manage any transitional period and it would be inappropriate for the legislation to impose limitations or restriction in this respect."219 Eight months later, however, Lord Falconer successfully moved an amendment to the Bill with the effect that the Supreme Court would not come into force unless the Lord Chancellor was satisfied that the court would 'be provided with accommodation in accordance with written plans that he has approved' (now section 148(4) of the Act). The Lord Chancellor will only be able to approve such plans if, having consulted the existing Law Lords at the time of the approval, he was 'satisfied that accommodation in accordance with the plans will be appropriate for the purposes of the Court.' (Section 148(5)).

Lastly, it is suggested that the architecture of the building in which the Supreme Court is to be housed must be appropriate to the constitutional standing of the court as the final court of appeal, viz., The Supreme Court of the United Kingdom. In this context, Sir Sydney Kentridge indicated that a new Supreme Court would merit the architecture of a building comparable with the Supreme Courts in Ottawa, Canberra and Washington. ${ }^{220}$ This would undoubtedly serve to act as a clear public demonstration of the constitutional significance and importance attached to a newly constituted Supreme Court. In a written statement in December 2004, Lord Falconer expressed the hope that the Supreme Court's first sitting in its accommodation in Middlesex Guildhall (his preferred option) would be in 2008, ${ }^{221}$ and later, in the House of Commons, Christopher Leslie reaffirmed that the Government's preferred option was for Middlesex Guildhall to be the location of the new Supreme Court. ${ }^{222}$ For its part, the Constitutional Affairs Committee in its report in January 2005 noted that this particular building would have the potential to be the seat of the Supreme Court provided that it was suitably adapted to enable "the new court to function as a modern appellate court." 223

\section{Conclusion}

In conclusion, the establishment of a Supreme Court is to be welcomed as it will place the United Kingdom's uncodifed constitutional arrangements on a modern footing by finally severing the highest court of appeal from Parliament. It would provide much needed clarity and transparency into the institutional structure of the constitution and would specifically integrate with two other recent constitutional reforms viz., the devolution settlement and the Human Rights Act. Accordingly, Part 3 of the Constitutional Reform Act 2005 will represent a watershed for the judicial arm of the constitution and will result in the United Kingdom, like New Zealand, who themselves have recently established a Supreme Court in Wellington, beginning the $21^{\text {st }}$ century armed with new arrangements in respect of the

\footnotetext{
219 Supra, n.23 at para.30.

220 Supra, n.183 at p.57.

221 HL Official Report vol.667 WS 71-73 14 December 2004.

222 HC Official Report vol.429 col.565 17 January 2005.

223 Supra, n.64 at p.19.
} 
final court of appeal. ${ }^{224}$ Notwithstanding this, although the new Supreme Court would be physically, legally and visibly separate from Parliament and represent a significant shift in our constitutional arrangements, Andrew Le Sueur has stressed that in terms of the court's composition, powers and jurisdiction, the Government, in drafting Part 2 of the Bill (now Part 3 of the Act) "rejected almost every innovation that could have been introduced". ${ }^{225}$ In other words, the new Supreme Court, apart from the new jurisdiction to process devolution issues, would simply be a transplantation of the current Appellate Committee. Indeed, Baroness Hale opined that, in view of the upheaval that would necessarily result from the establishment of a new Supreme Court, whether in these circumstances it was perhaps worth undertaking something more radical with the court? ${ }^{226}$ Finally, if the new Supreme Court is to be housed in Middlesex Guildhall, Christopher Leslie has rather poignantly commented that this would result in Parliament Square in London being flanked by all three arms of the constitution, viz., the legislature in the Palace of Westminster, the executive in Whitehall and the judiciary in the form of the Supreme Court in the Middlesex Guildhall. ${ }^{227}$

224 The Supreme Court Act 2003 (NZ). On the New Zealand Supreme Court see: R. Cornes, "Appealing to history: the New Zealand Supreme Court debate" (2004) 24 L.S. 210.

225 Supra, n.3 at p.331.

226 Supra, n.193 at p.42.

227 HC Official Report vol.430 col.737 1 February 2005. 